\title{
Pertumbuhan Populasi Cacing Tanah (Phertima sp.) sebagai Sumber Protein Pakan Ikan dalam Media Kotoran Kambing dengan Tiga Pakan Tambahan (Bungkil Sawit, Limbah Sayuran Pasar dan Dedak)
}

\section{Earthworm (Pheretima sp.) Population Growth as a Source of Protein Fish Feed on the Manure Goat Media with Three Feed Supplement (palm oil cake, Bran and Waste Vegetable Market)}

\author{
Ratna Mariyana, Mu'arif, dan Chumaidi
}

\begin{abstract}
The purpose of this research are to know the effect the addition of palm oil cake, bran and fermented vegetable waste on the manure goat media toward growth of population earthworm as a source of protein fish feed. Earthworms test used in this research is a type of Pheretima sp. as much as 100 individu/container. The design used in this research is Completely Randomized Design (CRD) with four treatments and three replications. Treatments were given different types of feed supplement that is without additional feed, palm oil cake, rice bran and waste vegetable market (a fermented) given every two day as much as 500 grams. The parameters observed in this research is population growth, weight and length of earthworms, and media quality (temperature and $\mathrm{pH}$ ). Research results showed that the treatment without additional feed (control A) have the highest of population growth of earthworms with the average of 12.1 ind liter, but the highest average of weight and length of earthworms were in the treatment of adding additional feed bran (D) respectively are 0.78 grams and $10.7 \mathrm{~cm}$.
\end{abstract}

\section{ABSTRAK}

Tujuan penelitian ini ialah untuk menganalisis pengaruh penambahan bungkil sawit, limbah sayuran hasil fermentasi dan dedak pada media kotoran kambing terhadap pertumbuhan populasi cacing tanah sebagai sumber protein pakan ikan. Cacing tanah uji yang dipergunakan pada penelitian ini ialah jenis Pheretima sp. sebanyak 100 individu/wadah. Rancangan percobaan dalam penelitian ini ialah Rancangan Acak Lengkap (RAL) dengan 4 perlakuan dan 3 ulangan. Perlakuan yang diberikan ialah perbedaan jenis pakan tambahan yaitu tanpa pakan tambahan / kontrol (A), bungkil sawit (B), limbah sayuran pasar hasil fermentasi (C) dan dedak (D) yang diberikan setiap dua hari sekali sebanyak 500 gram. Parameter yang diobservasi pada penelitian ini ialah pertumbuhan populasi, bobot dan panjang cacing tanah serta kualitas media (suhu dan $\mathrm{pH}$ ). Hasil penelitian menunjukkan bahwa pertumbuhan populasi cacing tanah tertinggi terdapat pada perlakuan (A) yaitu rata-rata 12,1 individu/liter, sedangkan rataan tertinggi untuk bobot dan panjang individu terdapat pada perlakuan (D) masing-masing 0,78 gram dan $10,7 \mathrm{~cm}$.

Ratna Mariyana, Mua'rif, dan Chumaidi. 2017. Pertumbuhan Populasi Cacing Tanah (Phertima sp.) sebagai Sumber Protein Pakan Ikan dalam Media Kotoran Kambing dengan Tiga Pakan Tambahan (Bungkil Sawit, Limbah Sayuran Pasar dan Dedak. Jurnal Mina Sains 3(1): 8-18.

\section{PENDAHULUAN}

\section{Latar Belakang}

Sektor perikanan termasuk salah satu potensi yang dimiliki oleh Indonesia sebagai negara yang $70 \%$ wilayahnya berupa perairan dimana pada sektor tersebut masih sangat prospektif untuk dikembangkan. Sektor perikanan memegang peranan penting dalam menghadapi krisis ekonomi yang dihadapi Indonesia beberapa tahun terakhir ini dan bisa menyerap tenaga kerja yang banyak. Salah satu usaha di sektor perikanan yang banyak digeluti masyarakat tersebut adalah budidaya ikan.

Kegiatan budidaya ikan terutama fase pembesaran pada umumnya memerlukan biaya 
operasional yang cukup besar. Faktor pakan merupakan penyumbang tertinggi pada biaya operasional. Hal tersebut dikarenakan harga salah satu material baku pakan yaitu tepung ikan sebagai sumber protein cukup tinggi, dibandingkan tepung cacing tanah (Dharmawan 2008). Oleh karena itu diperlukan sumber protein alternatif lain yang dimanfaatkan sebagai material baku pakan sehingga bisa menekan biaya operasional pada kegiatan pembesaran ikan. Salah satu sumber protein alternatif sebagai pengganti tepung ikan untuk bahan baku pakan adalah tepung cacing tanah. Salah satu jenis cacing tanah yang dapat dimanfaatkan yaitu Pheretima sp.

Akhir-akhir ini cacing tanah sebagai sumber protein hewani dimanfaatkan sebagai pengganti tepung ikan untuk ransum pakan ternak dan ikan. Apalagi diketahui bahwa sumber protein cacing tanah lebih tinggi dibandingkan tepung ikan, dan juga dapat dibuat dalam berbagai bentuk, yaitu bentuk tepung, kering, dan lainnya (Tommy 2009). Di negara lain cacing tanah dimanfaatkan sebagai bahan obat, bahan kosmetik, pengurai tanah dan penyubur tanah (Susetyarini 2007).

Menurut Palungkun (1999), tepung cacing tanah mengandung protein yang lebih besar dibandingkan dengan tepung ikan, yaitu mencapai 64-76\%, sedangkan tepung ikan hanya 58\%. Tepung cacing tanah juga mengandung asam amino paling lengkap, berlemak rendah, mudah dicerna dan tidak mengandung racun.

Chumaidi (2004) menyatakan bahwa ikan-ikan hias apapun bila diberi pakan cacing tanah rata-rata dapat merespon dengan baik yang ditandai dengan habisnya cacing yang diberikan dalam waktu singkat.

Cacing tanah memiliki potensi yang menguntungkan bagi kehidupan dan kesejahteraan manusia. Selama ini cacing tanah dianggap binatang yang menjijikkan dan kurang diberdayakan oleh bangsa Indonesia, oleh karena itu budidaya cacing belum banyak dilakukan peternak di Indonesia dibandingkan dengan negara-negara lain seperti Amerika Serikat, Filipina, Jepang, Taiwan dan beberapa negara Eropa serta Australia. Budidaya cacing tanah di Indonesia masih merupakan hal yang baru (Budiarti 1993 dalam Susetyarini 2007).
Menurut Gaddie dan Douglas (1977), kotoran binatang adalah habitat utama cacing tanah dan hampir secara keseluruhan cocok, baik sebagai sarang ataupun sebagai bahan makanan. Pemberian kotoran ternak dan ampas tebu meningkatkan reproduksi cacing tanah, pada rasio kotoran ternak : ampas tebu 1:1 dan 3:1 (Aquino et al. 1994). Selain kotoran hewan, limbah industri dan pertanian, seperti serbuk gergaji, serutan kayu, kompos sampah, dedak, jerami, rumput dan daun-daunan dapat dimanfaatkan sebagai bahan pembuatan sarang budidaya cacing tanah (Mulyani 1995 ).

Dedak, bungkil sawit dan limbah sayuran pasar termasuk salah satu jenis material yang dapat dipergunakan sebagai pakan tambahan pada budidaya cacing tanah. Dedak dan bungkil sawit memiliki kandungan protein cukup tinggi yang dibutuhkan untuk pertumbuhan cacing tanah. Harga yang relatif murah dan mudah didapatkan terutama untuk dedak dan limbah sayuran pasar bisa dijadikan alternatif pakan tambahan bagi kegiatan pemeliharaan cacing tanah.

Salah satu hewan ternak yang cukup berpontesi sebagai sumber kompos atau pupuk organik pada kegiatan kultur cacing tanah ialah kambing. Berdasarkan data hasil penelitian Balai Penelitian Ternak Ciawi bahwa di daerah Cirebon, Bogor dan Garut, setiap petani ratarata memiliki kambing-domba 6,32 ekor. Ratarata setiap ekor ternak membutuhkan pakan hijau segar 5,35 kg/hari atau 33,3 kg/peternak. Berdasarkan hasil perhitungan, dari jumlah pakan yang dikonsumsi tersebut, $4 \mathrm{~kg}$ akan dikeluarkan sebagai feses (bahan kering feses $45 \%$ ) per hari per 6,32 ekor. Selain itu sisa paka hijauan yang terbuang berkisar $40-50 \%$ atau $14,2 \mathrm{~kg}$. Dengan demikian, feses dan sisa hijauan yang bisa dikumpulkan dalam sehari sebagai material kompos bisa sebesar 18,2 kg untuk setiap peternak.

Potensi yang sangat besar dari kotoran kambing tersebut, dan didukung dengan daerah-daerah tertentu yang termasuk sentra peternakan sekaligus sentra perikanan seperti wilayah Kabupaten Bogor, diperlukan sinergi dan integrasi sehingga kotoran yang dihasilkan dari peternakan kambing bisa dimanfaatkan untuk media tumbuh cacing tanah. Cacing tanah sebagai pakan alternatif tambahan pada pemeliharaan ikan ataupun dimanfaatkan 
menjadi tepung cacing tanah pengganti tepung ikan sebagai bahan pakan buatan. Namun masyarakat pada umumnya masih belum mampu mencapai hasil budidaya yang optimal dengan memanfaatkan kotoran kambing sebagai media tumbuh cacing tanah. Berdasarkan pertimbangan tersebut maka penulis merasa perlu membuktikan keefektifan dari penggunaan kompos kotoran kambing sebagai media kultur cacing tanah disertai penambahan berbagai pakan tambahan melalui penelitian.

\section{Tujuan Penelitian}

Penelitian ini bertujuan untuk mengetahui pengaruh penambahan bungkil sawit, limbah sayuran (hasil fermentasi) dan dedak pada media kotoran kambing terhadap pertumbuhan populasi cacing tanah (Pheretima sp.) sebagai sumber protein pakan ikan.

\section{Hipotesis}

Penggunaan kotoran kambing sebagai media tumbuh dengan penambahan pakan tambahan (Bungkil Sawit, Limbah Sayuran Pasar (hasil fermentasi) dan Dedak) sebanyak 500 gram setiap dua hari sekali dapat meningkatkan pertumbuhan populasi cacing tanah (Pheretima sp.).

\section{BAHAN DAN METODE Waktu dan Tempat Penelitian}

Penelitian ini dilaksanakan pada tanggal 1 Maret 2012 s/d 28 Februari 2013. Sedangkan kegiatan penelitian di lapangan dilakukan pada tanggal 9 April s/d 16 Juni 2012 di Balai Penelitian dan Pengembangan Budidaya Ikan Hias (BPPBIH) Depok, Kota Depok, Jawa Barat.

\section{Alat dan Bahan}

Alat yang dipergunakan pada penelitian ini antara lain yaitu : (1) wadah berupa bak beton sebanyak 12 buah dengan luas 1 (satu) $\mathrm{m}^{2}$ dan tinggi $50 \mathrm{~cm}$ yang ditutupi dengan asbes, (2) timbangan digital yang mempunyai ketelitian hingga 0,01 g, (3) mistar dengan ketelitian $0,1 \mathrm{~cm}$, (4) thermometer, (4) $\mathrm{pH}$ meter, dan (5) pipa paralon alat sampling diameter $10 \mathrm{~cm}$ dan tinggi $20 \mathrm{~cm}$.

Bahan yang dipergunakan pada penelitian ini antara lain yaitu : (1) cacing tanah uji yang digunakan ialah jenis Pheretima sp. yang diperoleh dari BPPBIH, Depok dengan padat penebaran adalah 100 individu/wadah, (2) media hidup cacing tanah adalah $100 \%$ kompos kotoran kambing yang diperoleh dari peternak kambing di daerah Depok, dan (3) pakan cacing tanah yang terdiri dari bungkil sawit, dedak dan limbah sayuran pasar (kol dan sawi yang sudah difermentasi dengan menggunakan EM4).

\section{Pengelolaan Budidaya Persiapan}

Wadah uji berupa bak beton berukuran $1 \mathrm{~m} \times 1 \mathrm{~m} \times 0,25 \mathrm{~m}$ yang berjumlah 12 buah, masing-masing diisi dengan $100 \%$ kompos kotoran kambing dengan tinggi $0,2 \mathrm{~m}$ atau dengan volume $0,2 \mathrm{~m}^{3}$ (200 1). Media yang dipergunakan dalam kondisi $\mathrm{pH} 6-7$ dan temperatur di bawah $30^{\circ} \mathrm{C}$ dengan kelembaban yang cukup.

\section{Penebaran}

Media yang siap dan sudah dalam kondisi layak untuk pertumbuhan dan perkembangbiakan pada masing-masing wadah selanjutnya ditebar cacing tanah dengan padat tebar yaitu 100 individu/wadah atau 0,5 individu/liter. Cacing yang akan ditebar terlebih dahulu ditimbang dengan menggunakan timbangan digital dan rata-rata memiliki bobot individu berkisar antara 0,8-1 gram serta panjang individu berkisar antara $11-22 \mathrm{~cm}$.

Kondisi cacing tanah diamati setelah penebaran dilakukan dengan tujuan untuk memastikan apakah cacing tanah tersebut mau masuk ke dalam media. Cacing tanah masuk ke dalam media maka dapat dipastikan media kompos kambing tersebut sudah cocok untuk hidup, pertumbuhan dan perkembangbiakan.

\section{Pengelolaan Rutin}

Pengelolaan rutin pada budidaya cacing tanah antara lain yaitu :

1. Pemberian pakan tambahan

Penambahan pakan tambahan cacing tanah diberikan setiap 2 hari sekali sebanyak 500 gram dengan menggunakan bungkil sawit, dedak dan limbah sayuran pasar (kol dan sawi yang telah difermentasi dengan EM4) serta tanpa pemberian pakan 
sebagai kontrol masing-masing diulang 3 kali. Pakan tersebut disebarkan secara merata di atas permukaan media kultur cacing yang selanjutnya disiram dengan air agar pakan tersebut masuk ke dalam media sehingga memudahkan cacing tanah untuk memakannya.

Pakan tambahan berupa bungkil sawit dan dedak diperoleh dari pedagang di daerah Depok. Sedangkan limbah sayuran yang berupa sawi dan kol diperoleh dari pasar Pucung, Depok. Limbah sayur tersebut sebelum dijadikan pakan cacing difermentasi terlebih dahulu dengan menggunakan EM4.

Teknik fermentasi limbah sayuran pasar (sawi dan kol) dengan EM4 antara lain yaitu :

a. Penyiapan bahan dan alat yang dipergunakan seperti limbah sayuran pasar yang berupa kol dan sawi, gula pasir, EM4, bak plastik, pisau, talenan dan plastik

b. Limbah sayur yang diperoleh dari pasar disortir dari kotoran-kotoran lain

c. Limbah sayur dicuci hingga bersih.

d. Limbah sayur dipotong-potong dengan ukuran $3-5 \mathrm{~cm}$ sehingga volume lebih kecil untuk mempercepat proses fermentasi.

e. Penimbangan limbah sayuran tersebut untuk menentukan jumlah gula, air dan EM4 yang akan digunakan. Perbandingan antara limbah sayuran pasar : gula : EM4 : air yaitu $2.5 \mathrm{~kg}: 1 / 4$ sendok makan : $4 \mathrm{ml}: 300 \mathrm{ml}$.

f. Pencampuran limbah sayuran, gula, air dan EM4 menjadi satu agar proses fermentasi berjalan dengan lebih cepat.

g. Campuran limbah sayuran tersebut dimasukkan ke dalam plastik kemudian menutup rapat untuk mendapatkan kondisi anaerob untuk proses fermentasi.

h. Proses fermentasi berlangsung selama 5 (lima) hari.

i. Limbah sayuran hasil fermentasi siap untuk digunakan.

2. Pengelolaan air

Air sangat penting untuk kehidupan cacing tanah dan untuk menjaga agar media tumbuh cacing tanah tetap dalam kondisi lembab, maka setiap 2 hari sekali bersamaan dengan pemberian pakan maka media ditambahkan air. Penambahan air dengan cara menyemprotkan air ke media menggunakan slang yang selanjutnya diamati tekstur media tersebut. Jika media terlalu padat, maka dilakukan pembalikan supaya aerasi berjalan baik.

3. Sampling

Pengambilan sampel cacing tanah dilakukan setiap 10 hari sekali. Pengukuran suhu dan $\mathrm{pH}$ lingkungan dilakukan setiap 10 hari sekali selama 60 hari penelitian sejak penebaran awal cacing tanah ke dalam media. Pengambilan sampel dilakukan pada lima titik setiap wadah percobaan yaitu bagian 4 (empat) sudut dan 1 (satu) bagian tengah. Pengambilan sampel cacing tanah (Pheretima sp.) dilakukan dengan cara menggunakan pipa paralon berdiameter $10 \mathrm{~cm}$ dan tinggi 25 $\mathrm{cm}$ ke dalam subtrat, dan kemudian pipa paralon tersebut diangkat. Selanjutnya subtrat yang ada dalam pipa dikeluarkan kemudian cacing dipisahkan dengan menggunakan tangan. Cacing tanah dipisahkan dari media dengan metode hand-sorting yaitu memisahkan secara manual lalu ditimbang dengan timbangan digital.

\section{Metode Penelitian}

\section{Rancangan Perlakuan}

Rancangan percobaan yang dipergunakan dalam penelitian ini yakni Rancangan Acak Lengkap (RAL) dengan 4 perlakuan dan 3 kali ulangan. Adapun keempat perlakuan tersebut adalah :

1. $\operatorname{Kontrol}(\mathrm{A})$

2. Bungkil sawit 500 gram / 2 hari (B)

3. Limbah sayuran pasar hasil fermentasi 500 gram / 2 hari (C)

4. Dedak 500 gram / 2 hari (D)

Parameter utama yang akan diteliti meliputi kepadatan populasi, bobot, dan panjang cacing tanah. Sedangkan parameter penunjang meliputi parameter kualitas media yaitu $\mathrm{pH}$ dan suhu.

Rancangan percobaan yang digunakan pada penelitian ini adalah Rancangan Acak Lengkap (RAL) dengan jumlah perlakuan sebanyak $4 \mathrm{t}$ buah dan masing-masing 
perlakuan diulang 3 kali dan menggunakan model persamaan berdasarkan Steel dan Torrie (1991) sebagai berikut :

Keterangan

$$
\mathbf{Y i j}=\boldsymbol{\mu}+\boldsymbol{\alpha i}+\boldsymbol{\varepsilon i j}
$$

Yij : Nilai pengamatan pada perlakuan ke-i dan ulangan ke-j

$\mu \quad$ : Rata-rata umum

ai : Pengaruh perlakuan ke-i $(1,2,3,4)$

$€$ ij : Galat perlakuan ke-i dan ulangan ke-j

i : Perlakuan (A, B, C, D)

$\mathrm{j} \quad$ : Ulangan $(1,2,3)$

Data yang diperoleh selama penelitian dianalisis menggunakan sidik ragam (ANOVA) dan untuk mengetahui perbedaan antar perlakuan digunakan uji Beda Nyata Jujur (BNJ) atau uji Tukey (Vincent 1991). Proses analisis tersebut dilakukan dengan menggunakan software program JMP 7. Data yang digunakan untuk analisis yaitu data akhir hasil penelitian (hari ke-60) yang sebelumnya data penelitian tersebut ditansformasi terlebih dahulu ke akar kuadrat (Vincent 1991). Transformasi data dilakukan untuk memperoleh kestabilan ragam sehingga proses pengujian dapat mendekati kesahihan.

\section{Pengukuran Kualitas Lingkungan Media Cacing Tanah}

Pengukuran kepadatan populasi cacing tanah dihitung berdasarkan jumlah cacing tanah yang didapatkan pada saat sampling yang selanjutnya dikonversikan ke dalam satuan individu per liter. Untuk mengetahui bobot cacing tanah, cacing tanah yang didapatkan saat sampling ditimbang menggunakan neraca digital dengan ketelitian 0,01 g. Pengukuran biomassa cacing, secara acak diambil cacing tanah minimal 10 ekor dari setiap contoh yang didapatkan dari hasil sampling pada setiap wadah percobaan apabila didapatkan lebih dari 10 ekor sampel. Sedangkan untuk pengukuran panjang tubuh, secara acak diambil cacing tanah minimal 10 ekor dari setiap contoh yang didapatkan dari hasil sampling pada setiap wadah percobaan apabila didapatkan lebih dari 10 ekor sampel. Pengukuran panjang menggunakan mistar dengan ketelitian $0,1 \mathrm{~cm}$.

Pengukuran parameter penunjang seperti suhu media dilakukan setiap 10 hari sekali bersamaan dengan sampling dengan menggunakan thermometer. Teknik pengukuran suhu media yaitu dengan cara memasukkan thermometer ke dalam media dan didiamkan selama $2-5$ menit yang selanjutnya diamati hasilnya. Sedangkan pengukuran parameter $\mathrm{pH}$ media dilakukan setiap 10 (sepuluh) hari sekali bersamaan dengan sampling dengan menggunakan $\mathrm{pH}$ meter.

\section{HASIL DAN PEMBAHASAN Pertumbuhan Cacing Tanah Kepadatan Populasi Cacing Tanah}

Hasil pengamatan dari bulan April hingga Juni 2012, pertumbuhan populasi cacing tanah yang dikultur dalam bak beton pada masing-masing perlakuan dapat dilihat pada Gambar 1.

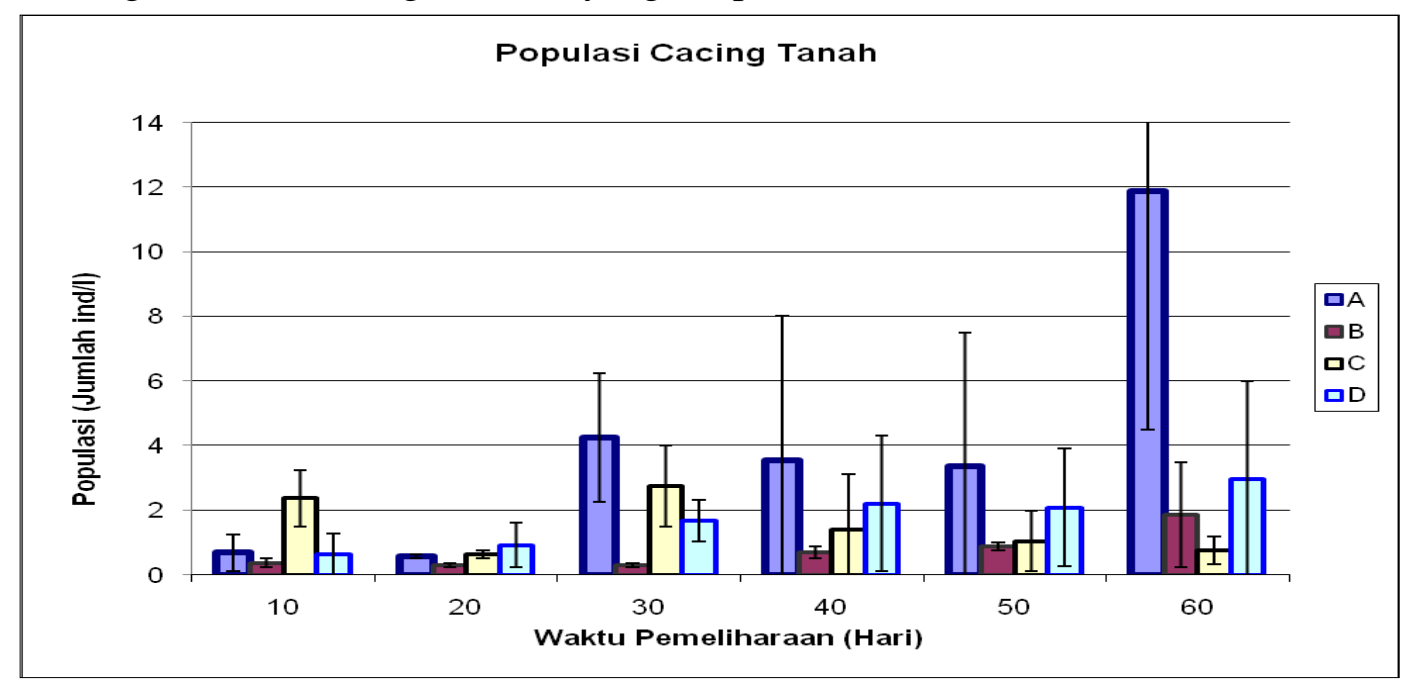

Keterangan $: A=$ media kontrol, $B=$ media yang ditambah bungkil, $C=$ media yang ditambah limbah sayuran, $D=$ media yang ditambah dedak

Gambar 1 Grafik populasi cacing tanah selama penelitian 
Gambar 1 menunjukkan bahwa rataan jumlah populasi cacing tanah untuk perlakuan tanpa pakan tambahan/kontrol (A) pada awal penelitian yaitu 6 ind $/ 7,85$ liter $(0,7$ ind/liter $)$, pada akhir penelitian 95 ind/7,85 liter $(12,10$ ind/liter). Rataan jumlah populasi cacing tanah yang ditambah pakan tambahan bungkil sawit (B) pada awal penelitian yaitu 3 ind/7,85 liter (0,38 ind/liter), pada akhir penelitian 15 ind/7,85 liter (1,91 ind/liter). Sedangkan rataan jumlah populasi cacing tanah yang ditambah pakan tambahan limbah sayuran pasar (C) pada awal penelitian $19 \mathrm{ind} / 7,85$ liter $(2,42 \mathrm{ind} / \mathrm{liter}$ ) menjadi 6 ind/7,85 liter (0,76 ind/liter) serta rataan jumlah populasi cacing tanah yang ditambah pakan dedak (D) pada awal penelitian 5 ind/7,85 liter $(0,64$ ind/liter $)$ menjadi 24 ind/7,85 liter (3,01 ind/liter).

Pada akhir penelitian (hari ke-60) rataan jumlah populasi cacing tanah tertinggi terdapat pada perlakuan tanpa pakan tambahan (kontrol) (A) sebesar 95 ind/7,85 liter $(12,10$ ind/liter) dan terendah pada perlakuan dengan penambahan pakan tambahan limbah sayuran (C) sebesar 6 ind/7,85 liter (0,76 ind/liter). Sedangkan populasi cacing tanah tertinggi selama penelitian untuk perlakuan tanpa pakan tambahan (A), pakan tambahan bungkil sawit (B) dan pakan tambahan Dedak (D) terjadi pada hari ke-60 sedangkan dengan pakan tambahan limbah sayuran pasar (C) pada hari ke-10. Hal tersebut mengindikasikan bahwa media kompos kambing bisa dipakai sebagai media yang baik untuk reproduksi cacing tanah.

Sihombing (2002) menyatakan bahwa kotoran binatang adalah habitat utama cacing tanah dan hampir sempurna sebagai makanan maupun sarang. Penggunaan kotoran binatang $100 \%$ merupakan media reproduksi untuk merangsang produksi kokon agar populasi cacing menjadi lebih banyak (Palungkun 1999). Kotoran hewan merupakan sumber kompos yang sangat penting karena kandungan unsur haranya sangat tinggi. Masing-masing jenis kotoran binatang mengandung unsur hara yang berbeda-beda. Semakin tinggi kandungan unsur semakin baik bahan itu (Suwardi 2004). Pernyataan tersebut sesuai dengan hasil penelitian yang dilakukan bahwa dengan penggunaan kompos kambing tanpa pakan tambahan dapat mengasilkan jumlah populasi yang relatif paling tinggi karena kompos kambing mengandung unsur hara yang tinggi. Kepadatan populasi yang berlebih menyebabkan cacing tanah menjadi kecil-kecil dan mungkin mengalami keracunan (Gaddie \& Douglas 1975).

Gambar 3 juga menunjukkan bahwa masih ada indikasi laju pertumbuhan populasi cacing tanah masih dapat bertambah seiring dengan lamanya waktu pemeliharaan. Hal ini cocok dengan pendapat Palungkun (1999) bahwa masa produktif cacing tanah $4-11$ bulan dan masa hidup cacing tanah $1-5$ tahun. Hasil pengukuran tersebut selanjutnya dianalisis untuk mengetahui pengaruh setiap perlakuan terhadap pertumbuhan populasi cacing tanah.

Hasil analisis populasi cacing tanah di akhir penelitian (hari ke-60) memperlihatkan bahwa perlakuan A (tanpa pakan tambahan/kontrol) memberikan pengaruh yang signifikan dibandingkan dengan perlakuan C (pakan tambahan limbah sayuran pasar). Antara Perlakuan A (tanpa pakan tambahan/kontrol), perlakuan B (pakan tambahan bungkil sawit) dan perlakuan D (pakan tambahan dedak) serta antara perlakuan B (pakan tambahan bungkil sawit), perlakuan C (pakan tambahan limbah sayuran pasar) dan perlakuan D (pakan tambahan dedak) tidak berbeda nyata.

\section{Bobot Individu Cacing Tanah}

Hasil pengamatan dari bulan April hingga Juni 2012, pertumbuhan bobot cacing tanah yang dikultur dalam bak beton pada masing-masing perlakuan dapat dilihat pada Gambar 2 . 


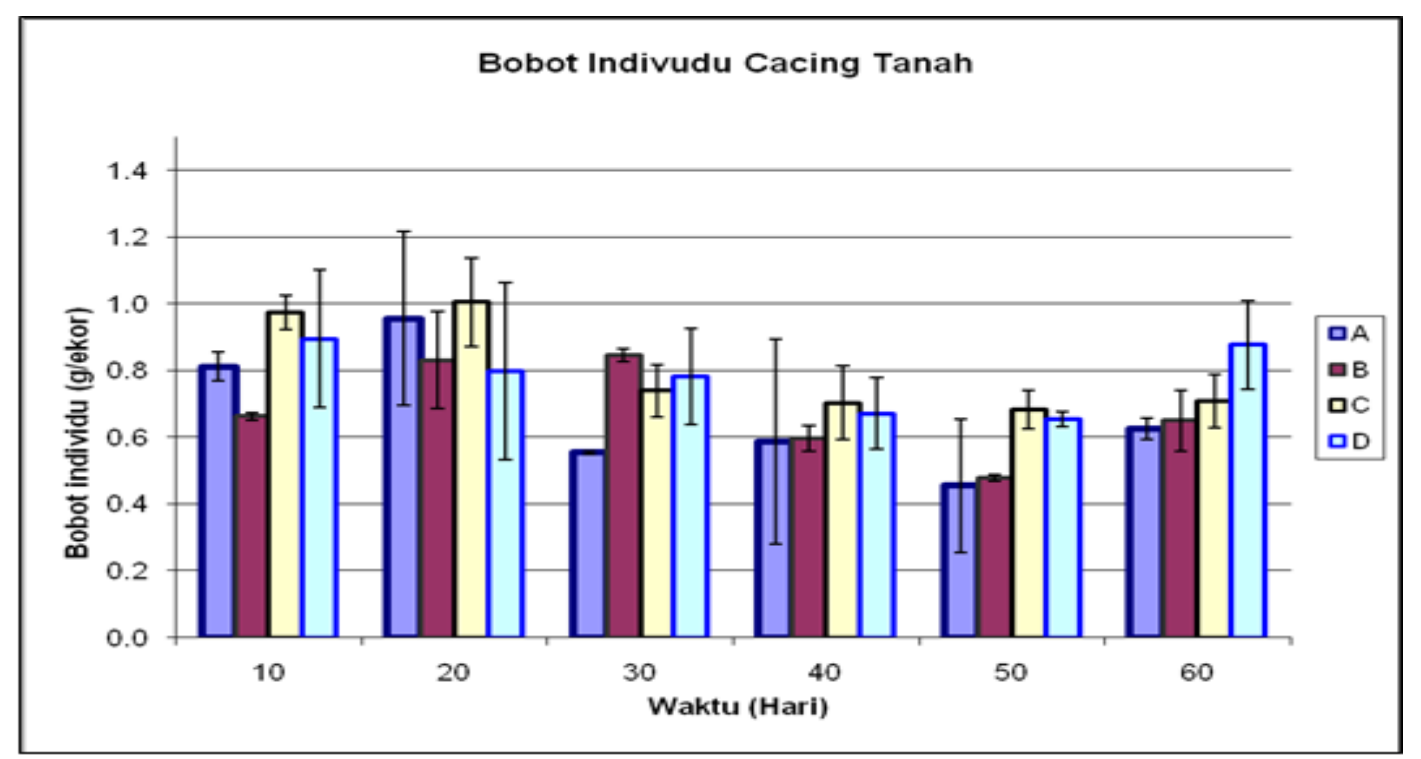

Keterangan : $A=$ media kontrol, $B=$ media yang ditambah bungkil, $C=$ media yang ditambah limbah sayuran, $D=$ media yang ditambah dedak

Gambar 2 Grafik bobot cacing tanah (Pheretima sp.) selama penelitian

Gambar 2 memperlihatkan bahwa rataan bobot cacing tanah untuk perlakuan tanpa pakan tambahan/kontrol (A) pada awal penelitian yaitu 0,66 gram menjadi 0,39 gram pada akhir penelitianm. Rataan bobot cacing tanah yang ditambah pakan tambahan bungkil sawit (B) pada awal penelitian yaitu 0,44 gram, pada akhir penelitian 0,43 gram. Sedangkan rataan bobot cacing tanah yang ditambah pakan tambahan limbah sayuran pasar (C) di awal penelitian 0,95 gram, pada akhir penelitian 0,51 gram serta rataana bobot cacing tanah yang ditambah pakan tambahan dedak (D) pada awal penelitian 0,83 gram, pada akhir penelitian 0,78 gram. Pada akhir penelitian (hari ke-60) rataan bobot cacing tanah tertinggi terdapat pada perlakuan dengan pakan tambahan dedak (D) sebesar 0,78 gram dan terendah pada perlakuan tanpa pakan tambahan/kontrol (A) sebesar 0,39 gram. Deputi Menegristek Bidang Pendayagunaan dan Pemasyarakatan Ilmu Pengetahuan dan Teknologi (2000), menyatakan bahwa dalam beternak cacing tanah ada dua hasil terpenting (utama) yang dapat diharapkan, yaitu biomas (cacing tanah itu sendiri) dan kascing (bekas cacing).

Chumaidi (2005) menjelaskan bahwa pengembangbiakan cacing tanah membutuhkan dua jenis bahan yaitu kompos organik sebagai tempat sekaligus pakan cacing dan pakan tambahan berupa beberapa jenis tepung seperti tepung-tepung kedelai, kelapa, ikan atau berbagai bungkil yang dihaluskan. Pakan cacing dapat pula berasal dari limbah sayuran pasar. Hasil penelitian memperlihatkan bobot tertinggi terdapat pada perlakuan dengan pakan tambahan dedak (D). National Research Council (NRC) - Nutrients Requirement of Poultry (1984) dalam Wahyuni (1995) menyatakan dedak padi mengandung energi metabolis sebesar $2100 \mathrm{kkal} / \mathrm{kg}$ dan zatzat makanan sebagai berikut : $12.90 \%$ protein, $13.00 \%$ lemak, $11.40 \%$ serat kasar, $0.07 \% \mathrm{Ca}$, $1.50 \% \mathrm{P}$ total dengan $0.21 \%$ non fitat $\mathrm{P}$ serta $0.22 \% \mathrm{Mg}$. Dedak padi juga kaya akan thiamin, niasin serta asam pantotenat. Jumlah kandungan zat-zat makanannya nampak bahwa dedak padi cukup baik sebagai bahan pakan.

Perkembangan cacing tanah mulai sampling ke-10 sampai sampling ke-60 menunjukkan bahwa cacing tanah yang didapatkan pada sampling ke-60 merupakan anakan karena bobot cacing tanah tersebut lebih kecil daripada bobot cacing tanah saat tebar sehingga cacing tanah tersebut masih dapat terus berkembang. Berbagai hal terkait dengan penyiapan pakan tersebut terutama terkait komposisi, kandungan air pakan, serta frekuensi pemberian pakan perlu lebih diperhatikan (Warsana 2009) sehingga pengaruh penambahan pakan luar tersebut lebih terlihat. 
Hasil analisis bobot individu cacing tanah di akhir penelitian (hari ke-60) memperlihatkan bahwa perlakuan A (tanpa pakan tambahan/kontrol) memberikan pengaruh yang signifikan dibandingkan dengan perlakuan D (pakan tambahan dedak). Antara Perlakuan A (tanpa pakan tambahan/kontrol), perlakuan B (pakan tambahan bungkil sawit) dan $\mathrm{C}$ (pakan tambahan limbah sayuran pasar) serta antara perlakuan B (pakan tambahan bungkil sawit), perlakuan $\mathrm{C}$ (pakan tambahan limbah sayuran pasar) dan perlakuan D (pakan tambahan dedak) tidak berbeda nyata.

\section{Panjang Cacing Tanah}

Penambahan pakan pada media pembiakan cacing tanah (kotoran kambing) selain mempengaruhi terhadap kepadatan populasi dan bobot cacing tanah, juga dapat mempengaruhi panjang cacing tanah yang dikembangbiakkan. Panjang cacing tanah dapat meningkat dengan cepat bila pakan yang diberikan cocok, dan akan terganggu dan bahkan dapat menyebabkan kematian bila pakan yang diberikan tidak cocok. Dalam penelitian, perlakuan dengan penambahan beberapa jenis pakan dimaksudkan untuk mengetahui pengaruh setiap jenis pakan yang ditambahkan sehingga dapat diketahui jenis pakan terbaik yang dapat mempercepat pertumbuhan cacing tanah yang nantinya dijadikan sebagai sumber protien ikan pada pakan budidaya.

Hasil pengamatan dari bulan April hingga Juni 2012, pertumbuhan panjang cacing tanah yang dipelihara dalam bak beton pada masing-masing perlakuan dapat dilihat pada Gambar 3.

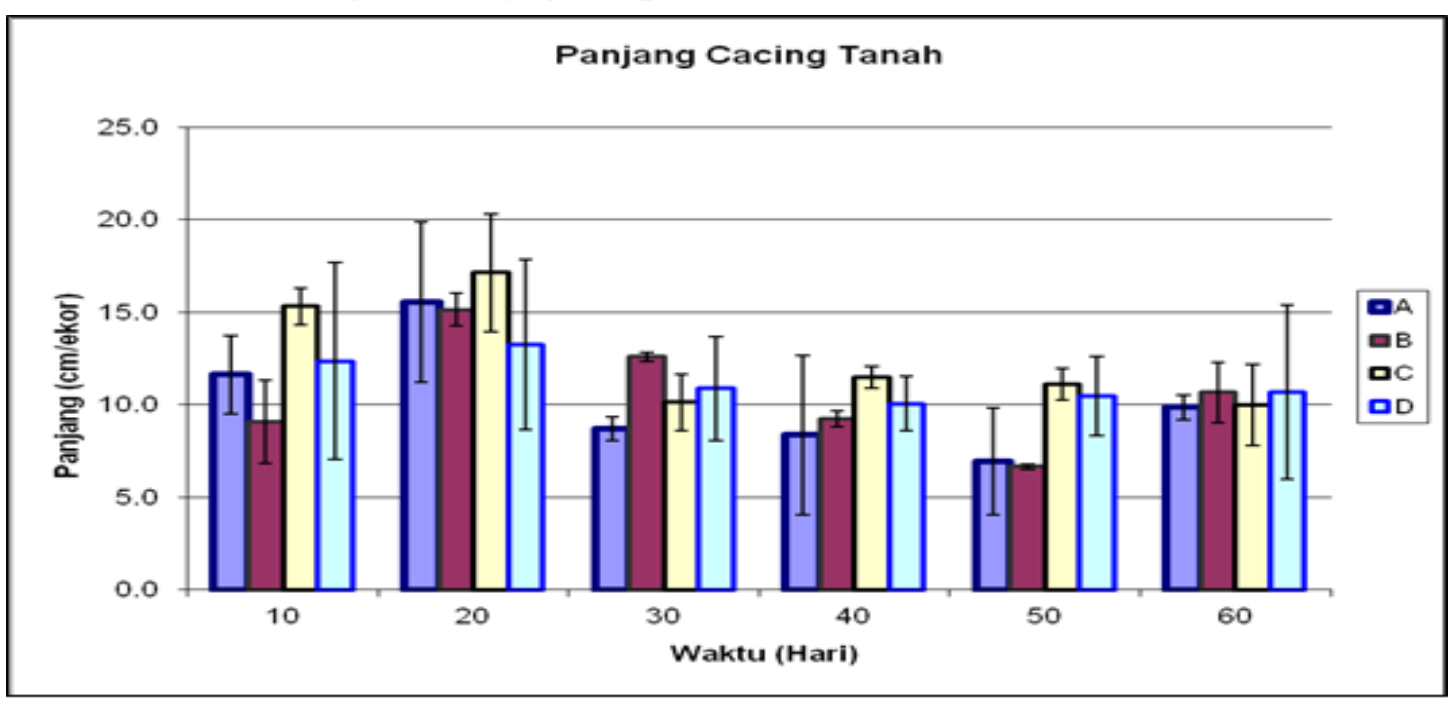

Keterangan : $A=$ media kontrol, $B=$ media yang ditambah bungkil, $C=$ media yang ditambah limbah sayuran, $D=$ media yang ditambah limbah sayuran

Gambar 3 Grafik panjang cacing tanah (Pheretima sp.) selama penelitian

Pada Gambar 3 memperlihatkan bahwa rataan panjang cacing tanah (Pheretima sp.) untuk perlakuan tanpa pakan tambahan/kontrol (A) pada awal penelitian yaitu $11,6 \mathrm{~cm}$, pada akhir penelitian $9,9 \mathrm{~cm}$. Rataan panjang cacing tanah yang ditambah pakan tambahan bungkil sawit (B) pada awal penelitian yaitu $9,1 \mathrm{~cm}$, pada akhir penelitian $10,7 \mathrm{~cm}$. Sedangkan rataan panjang cacing tanah yang ditambah pakan tambahan limbah sayuran pasar (C) pada awal penelitian $15,3 \mathrm{~cm}$, pada akhir penelitian $10 \mathrm{~cm}$ serta rataan panjang cacing tanah yang ditambah pakan tambahan dedak (D) pada awal penelitian $12,4 \mathrm{~cm}$, pada akhir penelitian $10,7 \mathrm{~cm}$.

Pada akhir penelitian (hari ke-60) panjang cacing tanah tertinggi terdapat pada perlakuan dengan pakan tambahan dedak (D) sebesar $10,7 \mathrm{~cm}$ dan terendah pada perlakuan tanpa pakan tambahan/kontrol (A) sebesar 6,6 $\mathrm{cm}$. Perkembangan cacing tanah mulai sampling ke-10 sampai sampling ke-60 maka hasil cacing tanah yang didapatkan pada sampling ke-60 merupakan anakan karena panjang cacing tanah tersebut lebih kecil daripada panjang cacing tanah saat tebar 
sehingga cacing tanah tersebut masih dapat terus berkembang.

Hasil analisis panjang cacing tanah pada akhir penelitian (hari ke-60) memperlihatkan bahwa setiap perlakuan memberikan pengaruh yang tidak signifikan antara setiap perlakuan yaitu A (tanpa pakan perlakuan tambahan/kontrol), perlakuan B (pakan tambahan bungkil sawit), perlakuan $\mathrm{C}$ (pakan tambahan dedak) dan perlakuan D (limbah sayuran pasar).

\section{Kualitas Lingkungan Media Pembiakan}

Media pembiakan yang dipergunakan dalam penelitian adalah kompos kambing dan kualitas lingkungan media kultur terutama $\mathrm{pH}$ dan suhu merupakan salah satu faktor penting untuk menentukan keberhasilan suatu usaha kultur cacing tanah. Hasil pengamatan dari bulan April hingga Juni 2012, terhadap suhu lingkungan media pembiakan cacing tanah dalam bak beton pada masing-masing perlakuan dapat dilihat pada Gambar 4.

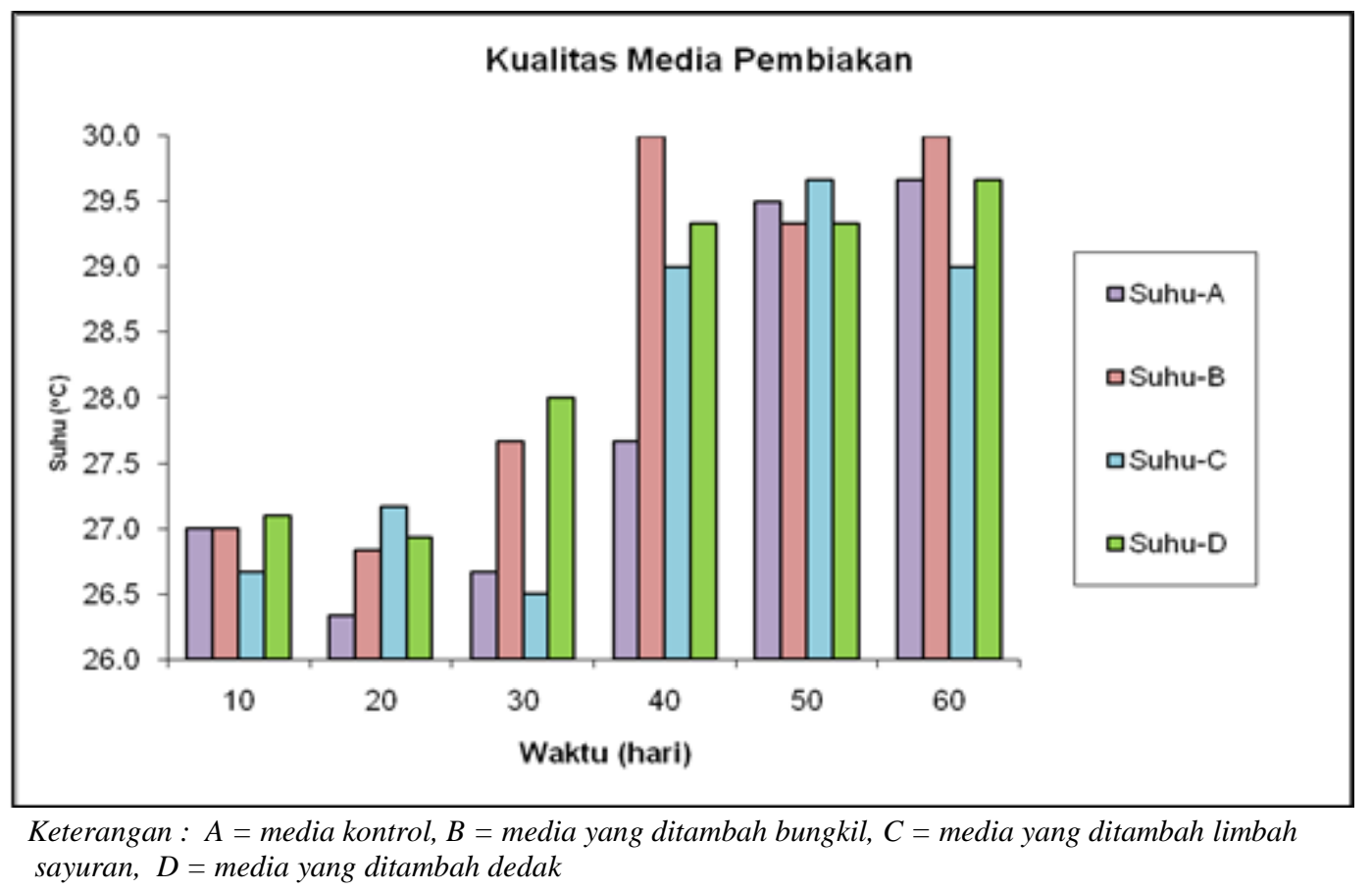

Gambar 4 Grafik suhu pada media pembiakan cacing tanah (Pheretima sp.) selama penelitian

Pada Gambar 4 memperlihatkan bahwa suhu pada media kultur cacing tanah untuk perlakuan tanpa pakan tambahan/kontrol (A) pada awal penelitian yaitu $27^{\circ} \mathrm{C}$ dan pada akhir penelitian $29,7^{\circ} \mathrm{C}$. Suhu media kultur yang ditambah pakan tambahan bungkil sawit (B) pada awal penelitian yaitu $27^{\circ} \mathrm{C}$ dan pada akhir penelitian $30^{\circ} \mathrm{C}$. Sedangkan suhu pada media kultur yang ditambah pakan tambahan limbah sayuran pasar (C) pada awal penelitian $26,7^{\circ} \mathrm{C}$, pada akhir penelitian $29^{\circ} \mathrm{C}$ serta suhu pada media kultur yang ditambah pakan tambahan dedak (D) pada awal penelitian $27,1^{\circ} \mathrm{C}$ dan pada akhir penelitian $29,7^{\circ} \mathrm{C}$.

Suhu pada media kultur cacing tanah pada setiap perlakuan relatif meningkat pada akhir penelitian dibandingkan dengan suhu awal penelitian. Suhu media yang relatif tinggi tersebut pada pemeliharaan hari ke-40 s.d ke60 disebabkan oleh pengaruh suhu lingkungan yang meningkat. Jika dilihat dari grafik, pada setiap waktu sampling kondisi suhu untuk tiga perlakuan yang ditambahkan pakan tambahan (bungkil sawit, dedak, limbah sayuran) relatif lebih tinggi daripada kondisi suhu media yang tanpa diberikan pakan tambahan/kontrol. Hal ini diduga bahwa perlakuan pada media yang ditambahkan pakan tambahan khususnya bungkil sawit dan dedak akan mengalami proses perombakan terlebih dahulu sebelum dimakan oleh cacing tanah, sehingga akan meningkatkan suhu media pembiakan cacing tanah. Kondisi suhu tersebut masih berada pada kisaran yang ditoleransi untuk kegiatan budidaya cacing tanah. Temperatur optimum untuk reproduksi cacing tanah adalah $21^{\circ} \mathrm{C}$ 
sampai $29^{\circ} \mathrm{C}$ dan untuk penetasan kokon adalah $26,7^{\circ} \mathrm{C}$ sampai $29^{\circ} \mathrm{C}$ (Catalan 1981 ).

Hasil pengamatan dari bulan April hingga Juni 2012, terhadap $\mathrm{pH}$ lingkungan media pembiakan cacing tanah (Pheretima sp.) dalam bak beton pada masing-masing perlakuan dapat dilihat pada Gambar 5.

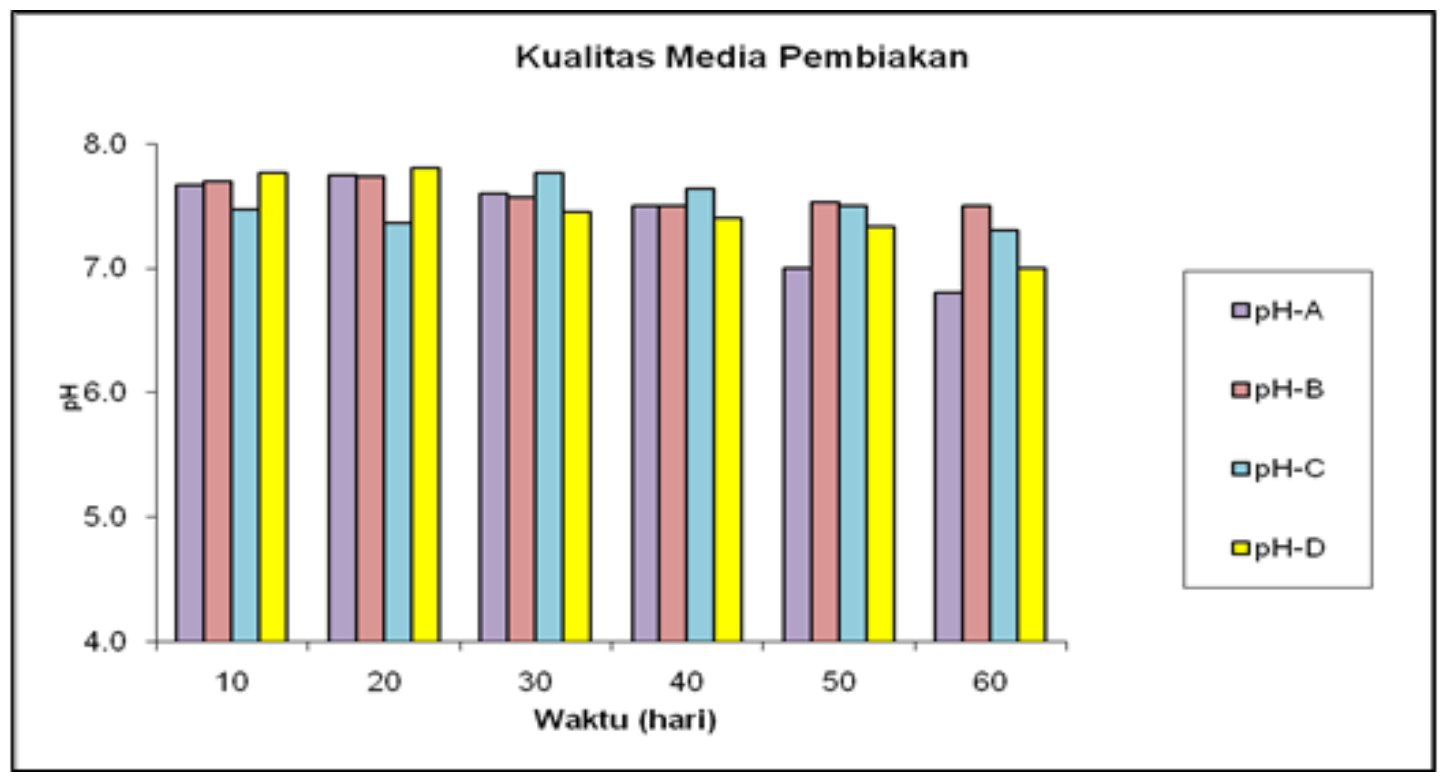

Keterangan : $A=$ media kontrol, $B=$ media yang ditambah bungkil, $C=$ media yang ditambah limbah sayuran, $D=$ media yang ditambah limbah sayuran

Gambar 5 Grafik pH pada media pembiakan cacing tanah (Pheretima sp.) selama penelitian

Gambar 5 juga menunjukkan bahwa derajat keasaman $(\mathrm{pH})$ pada media pembiakan cacing tanah (Pheretima sp.) untuk perlakuan tanpa pakan tambahan/kontrol (A) pada awal penelitian yaitu 7,67, pada akhir penelitian 6,80. $\mathrm{pH}$ media pembiakan yang ditambah pakan tambahan bungkil sawit (B) pada awal penelitian yaitu 7,70 , pada akhir penelitian 7,50. Sedangkan $\mathrm{pH}$ pada media pembiakan yang ditambah pakan tambahan limbah sayuran pasar (C) pada awal penelitian 7,47, pada akhir penelitian 7,30 serta $\mathrm{pH}$ pada media pembiakan yang ditambah pakan tambahan dedak (D) pada awal penelitian 7,77, pada akhir penelitian 7,00.

Derajat keasaman $(\mathrm{pH})$ pada media pembiakan cacing tanah pada setiap perlakuan relatif menurun pada akhir penelitian. Hal tersebut disebabkan oleh meningkatnya suhu lingkungan di sekitar wadah pemeliharaan sehingga aktivitas bakteri meningkat yang berakibat menurunnya $\mathrm{pH}$. Kondisi tersebut masih berada pada kisaran $\mathrm{pH}$ yang ditoleransi untuk kegiatan budidaya cacing tanah. Sihombing (2002) mengungkapkan cacing tanah memiliki enzim yang terbatas. $\mathrm{pH}$ media harus dijaga antara $6,8-7,2$ yaitu $\mathrm{pH}$ yang optimum bagi bakteri yang membantu dalam saluran pencernaan cacing tanah.

\section{KESIMPULAN DAN SARAN Kesimpulan}

Hasil penelitian menunjukkan bahwa pertumbuhan populasi cacing tanah (Pheretima sp.) pada akhir penelitian (hari ke-60) relatif paling tinggi terdapat pada perlakuan tanpa pakan tambahan/kontrol (A) yaitu rata-rata 95 ekor/7,85 liter (12,1 ind/liter) dan bobot ratarata cacing tanah (Pheretima sp.) relatif paling tinggi pada perlakuan penambahan pakan tambahan dedak (D) yaitu 0,78 gram. Hasil analisis uji lanjut menunjukkan bahwa pada perlakuan A, B, C dan D tidak memberikan pengaruh yang berbeda nyata terhadap panjang cacing tanah.

\section{Saran}

Saran penelitian lanjutan budidaya cacing tanah (Pheretima sp.) sebagai salah satu sumber protein pakan ikan pada media kompos kambing perlu dilakukan dengan rentang waktu pemeliharaan yang lebih lama minimal 
6 bulan sehingga benar-benar diketahui puncak populasi tertinggi sampai populasi cacing tanah tersebut semakin menurun.

\section{DAFTAR PUSTAKA}

Aquino AM, Almeida DE, Freire DL, Polli HDE. 1994. Earthworms (Oligochaeta) reproduction in manure and sugarcane bagasse. Pesquisa Agropecuaria Brasileria 29: 16-168.

Catalan GI. 1981. Earthworms a New Resource of Protein. Philippines: Philippine Earthworm Center.

Dharmawan MI. 2008. Pengaruh penggunaan tepung cacing tanah (lumbricus sp.) sebagai pengganti tepung ikan pada pakan buatan terhadap laju pertumbuhan, efisiensi pakan dan kelangsungan hidup benih ikan gurami (osphronemus gouramy) [skripsi]. Surabaya: FPIK Unair.

Gaddie RE, Douglas. 1975. Earthworm for ecology and profit. California: Bookworm Publishing Company Ontario.

Gaddie RE, Douglas. 1977. Earthworm for ecology and profit. California: Bookworm Publishing Company Ontario.

Menegristek Bidang Pendayagunaan dan Pemasyarakatan Ilmu Pengetahuan dan Teknologi. 2000. Budidaya Cacing Tanah (Lumbricus sp.). Kemal H (Editor). Jakarta: Kementerian Negara Riset dan Teknologi.
Mulyani D. 1995. Pengaruh campuran kotoran sapi dan alang-alang (Imperata cylindrica (l.) raeuschel) terhadap bobot tubuh, produksi kokon dan penyusutan sarang cacing tanah (Eisenia foetida savigny). [Skripsi]. Bogor: Institut Pertanian Bogor.

Palungkun R. 1999. Sukses beternak cacing tanah lumbricus rubellus. Jakarta: Penebar Swadaya.

Sihombing DTH. 2002. Pengantar ilmu dan teknologi budidaya wirausaha muda. Bogor: Satwa Harapan I.

Steel RGD, JH. Torrie. 1991. Prinsip-prinsip dan prosedur statistika. Terjemahan. Jakarta: PT. Gramedia Pustaka Utama.

Suwardi. 2004. Teknologi Pengomposan bahan organik sebagai pilar pertanian organik [Simposium Nasional ISSAAS]. Bogor: Institut Pertanian Bogor.

Tommy. 2009. Pembuatan pakan ikan alternatif dari bahan cacing tanah. http://cacinglumbricus.wordpress.com[5 agustus 2009].

Vincent G. 1991. Metode perancangan percobaan. Bandung: CV. Armico.

Wahyuni SHS. 1995. Biokonversi dedak padi oleh kapang aspergillus ficus sebagai upaya menurunkan kadar fitat dan pengaruhnya terhadap kinerja ayam petelur [Tesis]. Bogor: Program Pascasarjana, Institut Pertanian Bogor.

Warsana. 2009. Kompos cacing tanah (Casting). http://www.litbang.deptan.go.id. 